\title{
Elaboration and sensorial and physicochemical assessment of nectar from mixture of beet, carrot and orange juice
}

\author{
Evaluación fisicoquímica y sensorial de un néctar elaborado a partir \\ de una mezcla de jugo de zanahoria y naranja \\ Nelson Eduardo Loyola López ${ }^{1 *}$, Melisa Rojas Ubilla1, Carlos Acuña Carrasco ${ }^{1}$, \\ Mariela Aida Arriola Herrera ${ }^{1}$
}

\begin{abstract}
Five different nectars were elaborated, having a variable percentage of beet, carrot and orange in their formulation. As a general objective It was proposed to evaluate the sensorial, nutritional and hygienic features of nectars made from beet juice. Specific objectives were to assess chemical parameters such as; $\mathrm{pH}$, acidity and soluble solids in the elaborated nectar; to assess the nutritional content, expressed in Vitamin C and reducing sugars; to carry out a sensorial assessment on the elaborated nectar, expressed in color, aroma, sweetness, acidity, viscosity and acceptability; to assess the presence of mesophilic aerobes, according to the sanitary food regulations from Chile.

Nectars were standardized to a pH of 3.8 and soluble solids of $14^{\circ} \mathrm{Brix}$, showing a slight difference in the amount of sugar added. After packing, they were refrigerated at $7{ }^{\circ} \mathrm{C}$ and physicochemical parameters were measured at 0,15 and 30 days of storage. Sensorial and microbiological analyzes were carried out after 30 and 120 days of storage. The results of the physicochemical and sensorial analyzes were evaluated with a completely randomized design. For all statistical analyzes, a confidence level of $95 \%$ was determined. The acceptability of nectars with the highest score was the one elaborated in treatment $4\left(\mathrm{~T}_{4}\right)$, with $70 \%$ of beet juice, $15 \%$ of carrot juice and $15 \%$ of orange pulp in their formulation. At the time of the sensorial evaluation, this nectar showed a $\mathrm{pH}$ of 3.7 and a $0.20 \%$ titrable acidity, soluble solids of $14.3^{\circ}$ Brix, a vitamin C content of $6.3 \mathrm{mg} / 100 \mathrm{~g}$ of ascorbic acid and $1.7 \%$ of reducing sugars. The probable number of colony forming units was 13 and 36, thus all nectars showed a good microbiological quality after 120 days of storage.
\end{abstract}

Keywords: Beet, analysis, storage.

\section{RESUMEN}

Se elaboraron cinco néctares con distintos porcentajes de betarraga, zanahoria y naranja en su formulación. Como objetivo general se propuso evaluar la valoración sensorial, nutricional e higiene de un néctar a base de jugo de betarraga. Los objetivos específicos fueron medir parámetros químicos tales como $\mathrm{pH}$, acidez y sólidos solubles; determinar el contenido nutricional, expresado en vitamina C y azúcares reductores; analizar atributos sensoriales, expresados en color, aroma, dulzor, acidez, viscosidad y aceptabilidad; e identificar la presencia de mesófilos aerobios, según el reglamento sanitario de Chile.

Los néctares fueron estandarizados a un $\mathrm{pH}$ de 3,8 y sólidos solubles de $14^{\circ} \mathrm{Brix}$, agregando poca cantidad de azúcar. Una vez. envasados fueron refrigerados a $7{ }^{\circ} \mathrm{C}$ y los parámetros fisicoquímicos se midieron a los 0,15 y 30 días. El análisis sensorial se hizo a los 30 días de almacenamiento y el análisis microbiológico a los 120 días. Los resultados de los análisis fisicoquímicos y sensoriales fueron evaluados con un diseño completamente aleatorio. Para todos los análisis estadísticos se determinó un nivel de confianza del $95 \%$.

La aceptabilidad determinada por 13 panelistas semientrenados arrojó mayor puntaje al tratamiento 4 (T4), con un 70\% de jugo de betarraga, $15 \%$ de jugo de zanahoria y un $15 \%$ de pulpa de naranja en su formulación. Al momento de la evaluación sensorial este néctar presentó un $\mathrm{pH}$ de 3,7; 0,20\% de acidez titulable, sólidos solubles de 14,3 ${ }^{\circ}$ Brix, un contenido de vitamina $C$ de 6,3 $\mathrm{mg} / 100 \mathrm{~g}$ de ácido ascórbico y 1,7\% de azúcares reductores. El número probable de unidades formadoras de colonias fue 13 y 36, y todas presentaron una buena calidad microbiológica a los 120 días de almacenamiento.

Palabras clave: betarraga, análisis, almacenamiento.

1 Universidad Católica del Maule. Facultad de Ciencias Agrarias. Departamento de Ciencias Agrarias. Camino a Los Niches S/N, Km 6. Curicó, Chile.

* Autor por correspondencia: nloyola@ucm.cl.

Fecha de Recepción: 27 de Marzo, 2019.

Fecha de Aceptación: 21 Julio, 2019. 


\section{Introduction}

The non-alcoholic beverage market consists of soft drinks, water, juices, nectars, energy drinks and tea-based beverages. In recent years there was a strong growth in sales volume, from 1.8 million liters in 2001 to 3 million liters in 2011. Juices and nectars are some of the products that experienced a higher growth in the period 2006-2011, there was an increase of $16 \%$ in Chile and $17.2 \%$ in Latin America (Chilean Foundation, 2013). This increase is due to the fact that consumers are becoming aware of their diet and they prefer healthy and functional products in order to prevent or reduce the risk of diseases (Berto, 2003). The segment of non-alcoholic beverages has been innovating with the mixture of single vegetable juices or with fruit juices, due to this perception by consumers regarding vegetable juices and their impact on health (Kehr and Bórquez, 2010). Recently, "blends" or mixtures of fruits have been gaining strength in the market, since the combination of different fruits allows obtaining products with new flavors, colors, textures and with different nutritional components (Berto, 2003). The beet pigment, called betaciahnine, is a powerful antioxidant agent; in addition, this vegetable is rich in folic acid, potassium and Vitamin B (Neelwarne, 2012, Murray, et al., 2005). Orange, on the other hand, is a good source of vitamin C for the human diet, being the one that contains the highest percentage of this vitamin among citrus fruits (Baraona and Sancho, 1991). Meanwhile, carrot is a source of beta-carotene, which is transformed into Vitamin A in our organism (Bielefeld, 2004). As a contribution to the consumption of beet by its nutritional component, this work aims at developing qualified nectars with organoleptic attributes to be attractive for consumers, using beet juice as a propellant of this research. The study was aimed at finding the possibility of fully positioning beet in the nectar market, either completely with the elaboration of $100 \%$ beet nectar or partially due to the combination of beet with orange and carrot as mixed nectar. Both options offered new flavors to the range of nectars already existing in the market, thus becoming attractive since it also allowed combining the nutritional characteristics of each of the fruits and vegetables used in the study. In order to offer a truly innovative, attractive and innocuous option to agricultural producers, it was proposed as a general objective: to evaluate the sensorial, nutritional and hygienic features of nectars made from beet juice. As specific objectives: to assess chemical parameters such as; $\mathrm{pH}$, acidity and soluble solids in the elaborated nectar; to assess the nutritional content, expressed in Vitamin C and reducing sugars; to carry out a sensorial assessment on the elaborated nectar, expressed in color, aroma, sweetness, acidity, viscosity and acceptability, according to panelist's sensorial perceptions; to assess the presence of mesophilic aerobes, according to the sanitary food regulations from Chile.

\section{Materials and Methods}

The elaboration of nectar based on beet, carrot and orange juice was carried out in the Science laboratory from the School of Agronomy in the Universidad Católica del Maule, San Isidro campus, located at kilometer 6 , on the way to Los Niches, located west of the city of Curicó, Maule Region, Chile. The coordinates belonging to the campus are Latitude South 35'5'35.8002 "and Longitude West 71²8'1.9998" (Santibáñez and Uribe, 1993). Five treatments were elaborated for the trial, where each one had a proportion of beet, carrot and orange as variable (Table 1). These percentages corresponded to $25 \%$ of the total raw material, vegetables and fruits, used in the elaboration of nectar, where the remaining percentage corresponds to water and other inputs (Table 2).

\section{Methodology for the elaboration of nectars}

Beet, carrot and orange were selected, depending on the state of the physiological maturity they had; those fruits on ripe, green and with condition damages were rejected, as they were not optimal for the elaboration of nectar. The ones with an adequate maturity were cleaned by immersion in water with a solution of $1 \mathrm{~mL}$ of chlorine for each liter of water. Once finished, the raw material was drained for

Table 1. Description of the treatments.

\begin{tabular}{crcc}
\hline Treatments & Beet & Percentage Orange & $(\%)$ Carrot \\
\hline $\mathrm{T}_{0}$ & 100 & 0 & 0 \\
$\mathrm{~T}_{1}$ & 33 & 33 & 33 \\
$\mathrm{~T}_{2}$ & 50 & 25 & 25 \\
$\mathrm{~T}_{3}$ & 70 & 15 & 15 \\
$\mathrm{~T}_{4}$ & 90 & 5 & 5 \\
\hline
\end{tabular}


Table 2. Details of the treatments.

\begin{tabular}{lccccc}
\hline & \multicolumn{5}{c}{ Percentage (\%) } \\
\cline { 2 - 6 } & $\mathrm{T}_{0}$ & $\mathrm{~T}_{1}$ & $\mathrm{~T}_{2}$ & $\mathrm{~T}_{3}$ & $\mathrm{~T}_{4}$ \\
\hline Beet & 25 & 8.5 & 12.5 & 17.5 & 22.5 \\
Carrot & 0 & 8.25 & 6.25 & 3.75 & 1.25 \\
Orange & 0 & 8.25 & 6.25 & 3.75 & 1.25 \\
Raw Material & 25 & 25 & 25 & 25 & 25 \\
Water & 63.68 & 63.32 & 63.41 & 63.51 & 63.61 \\
Sugar & 11.1 & 11.46 & 11.37 & 11.27 & 11.17 \\
Sodium Benzoate & 0.02 & 0.02 & 0.02 & 0.02 & 0.02 \\
Gelly Gum & 0.2 & 0.2 & 0.2 & 0.2 & 0.2 \\
Cítric Acid & $(*)$ & $(*)$ & $(*)$ & $(*)$ & $(*)$ \\
Costs & 75 & 75 & 75 & 75 & 75 \\
Total & $100 \%$ & $100 \%$ & $100 \%$ & $100 \%$ & $100 \%$ \\
\hline
\end{tabular}

Source: Adapted by Gelymar, s.f

(*) The amount of citric acid depended on each treatment to standardize $\mathrm{pH}$ to 3.8 .

the conditioning process. The raw material was conditioned, for this aim the carrots were peeled and cut into $1 \mathrm{~cm}$ thick. For the formulation of nectars, it was considered that the soluble solid of the final product was $14{ }^{\circ} \mathrm{Brix}$ according to the following formula:

${ }^{\circ}$ Brix nectar $=\left(\left(\mathrm{X}\right.\right.$ g beet $\mathrm{x} 11,5^{\circ}$ Brix $)+(\mathrm{X}$ g carrot $\mathrm{x} 11^{\circ}$ Brix $)+\left(\mathrm{X}\right.$ g orange $\mathrm{x} 8^{\circ}$ Brix $\left.)\right) / 1000 \mathrm{~g}$

It was also necessary to know the weight corresponding to $34 \%$ of beet, $33 \%$ of orange and $33 \%$ of carrot for the $250 \mathrm{~g}$ of vegetable-fruit nectar so as to use each raw material for the formulation of Treatment 1. Table 3 details the amount $(\mathrm{g})$ needed to make one liter in treatment $\mathrm{T}_{1}$. Once the necessary weight of each raw material was known, the balance was made with the ${ }^{\circ} \mathrm{Brix}$ of the raw material which were previously obtained. The ${ }^{\circ}$ Brix of the nectar, excluding the addition of sugar was $2.54^{\circ} \mathrm{Brix}$; thus, $11.46 \mathrm{~g}$ of sugar were missing to reach a product of $14^{\circ} \mathrm{Brix}$. Knowing that the ${ }^{\circ} \mathrm{Brix}$ of sugar equals $100,114.6 \mathrm{~g}$ of sugar were needed to make one liter in Treatment 1.

Table 3. Required quantity of raw material for processing treatment $\mathrm{T}_{1}$.

\begin{tabular}{lll}
\hline & \multicolumn{1}{c}{$\mathrm{G}$} & $\%$ \\
\hline Beet & 85 & 34 \\
Carrot & 82.5 & 33 \\
Orange & 82.5 & 33 \\
\hline
\end{tabular}

\section{Methodology of Analysis}

Physicochemical analysis: These analyzes were carried out in three moments, being the first one at 0 days of nectar storage, the second one after 15 days of storage and the last one after 30 days. $\mathrm{pH}$ determination in the elaborated nectars was made with a pH-meter (A.O.A.C., 1990).

Determination of soluble solids: The determination of soluble solids was carried out according to the Official A.O.A.C. Method 932.12 (1990) solids soluble in fruits and fruit products.

Determination of titrable acidity: The titrable quantity of acid predominant in beet, carrot and orange mixed nectar was determined by the Official A.O.A.C .Method 942.15 acidity in fruit products (A.O.A.C., 1990), according to the following formula:

Acidity $(\%$ of citric acid $)=($ Cost of $\mathrm{NaOH} \times 0.1$ $\mathrm{N}$ de $\mathrm{NaOH} \times 0.064 \times 100) / \mathrm{mL}$ of diluted juice

Determination of ascorbic acid (Vitamin C): The determination of Vitamin C was carried out using the titrable A.O.A.C. 967.21 method of 2.6-dichloroindophenol analysis (A.O.A.C., 1990).

Preparation 2.6-dichlorophenol-indophenol: $0.1 \mathrm{~g}$ of the reagent was weighed on an analytical balance and the reagent was dissolved with distilled water in a $250 \mathrm{~mL}$ beaker. The glass was covered with alusa-foil so as not to expose the reagent to light and then it was stirred for one hour at a moderate speed. Later, it was filtered with a filter paper and it was completed at a volume of $250 \mathrm{~mL}$ with distilled water. 
Standardization of 2.6-dichlorophenolindophenol: An aliquot of $1 \mathrm{~mL}$ of 2.6- dichlorophenol -indophenol solution was taken in a centrifuge tube and a drop of $80 \%$ of acetic acid was added. When this was done, 2.6-dichlorophenol-indophenol turned from an intense blue color to a wine color. Then it was titrated with $40 \mathrm{mg} / 100$ of ascorbic acid by means of a burette, until the color of the solution changed from wine to colorless; then, the volume of ascorbic acid was registered (A.O.A.C., 1990).

Procedure for the determination of Vitamin C: A $1 \mathrm{~mL}$ of 2.6-dichlorophenol-indophenol was measured with a pipette in a test tube and 1 drop of $80 \%$ of acetic acid was added. It was titrated with diluted nectar of $10^{\circ} \mathrm{Brix}+/-2$, drop by drop with a partial pipette of $1 \mathrm{~mL}$. When a color change was observed, the volume was registered. Calculation:

$\mathrm{mg}$ ascorbic acid $/ 100 \mathrm{~g}$ sample $=(8 \mathrm{x}$ Standarization cost x 100)/ Diluted juice cost $\mathrm{x}{ }^{\circ}$ Brix of Diluted juice

Determination of reducing sugars: Was carried out by the Lane and Eynon method (A.O.A.C., 1990).

Determination of reducing sugars: An aliquot of $25 \mathrm{~mL}$ of the clarified solution was taken and placed in a $100 \mathrm{~mL}$ volumetric flask, diluted with distilled water, the flask was capped, stirred and the solution was transferred into a burette. In a $250 \mathrm{~mL}$ beaker, $5 \mathrm{~mL}$ of Fehling A and $5 \mathrm{~mL}$ of Fehling B were added, 3 drops of blue methylene were also added and diluted with distilled water. It was boiled on a hot plate by adding 7 glass beads and this solution was titrated with the clarified solution until the blue color disappeared.

Calculation: $\%$ of reducing sugars $=$ Total volumen x Fehling factor x 100 / Sample weight x Solution expenditure

Sensorial analysis: Once the nectar was elaborated, the sensorial analysis was performed after 30 days of storage, where 13 trained panelists participated. They had to taste and assess 3 random samples of each of the 5 treatments. The methodology they worked with was Espinosa (2007).

Among the attributes that make up a sensorial profile, those assessed in the mixed nectar were the following ones: color, aroma, texture, sweetness, acidity and acceptability (Adapted by Hernandez, 2005). Acceptability was measured with a verbal hedonic scale, where 1 represented 1 "I don't like it so much" and 9 "I like very much" (Adapted by Hernandez, 2005).
Microbiological analysis: The microbiological analysis was carried out after 120 days of storage using the plate count method ISO 4833-1 (ISO, 2013). As the seeding was duplicately done, the colonies were counted in the two plates and the average was obtained.

Experimental design: Two experimental designs were used, where the treatments were chosen at random and the experimental unit was $250 \mathrm{~mL}$ of elaborated nectar packed in a glass bottle. The data from the physicochemical analysis and from the sensorial study were analyzed in a completely randomized design. For this aim, an ANDEVA of one factor was used and in those cases where there was a significant difference, the Tukey test was performed with a significance level of 0.05 . Data was analyzed with the IBM-SPSS Statistics program, version 22.

\section{Results and Discussion}

\section{Physicochemical analysis}

PH measurement: $\mathrm{pH}$ values in the elaborated nectar based on beet juice, whose data are not shown, had a minimum value (3.5) in treatment $4\left(\mathrm{~T}_{4}\right)$ after 30 days of storage, while the maximum value (3.80) was obtained on day 0 in the nectars belonging to the control treatment $\left(\mathrm{T}_{0}\right)$, treatment $2\left(\mathrm{~T}_{2}\right)$ and treatment 4 $\left(\mathrm{T}_{4}\right)$. All treatments had a $\mathrm{pH}$ decrease after 30 days of storage, but the one that had a bigger decrease was treatment $4\left(\mathrm{~T}_{4}\right)$, from 3.8 to 3.5. According to the statistical analysis, there were significant differences ( $\mathrm{p}$-value 0.000 ) on $\mathrm{pH}$ in the nectars based on beet juice among the different treatments and the storage time. Nectars must have a $\mathrm{pH}$ lower than 4.5 since a high acidity prevents the growth of microorganisms (Practical Solutions-ITDG, 1997). The optimal pH, according to INEN (2008), is in a range between 3.5 and 4 ; thus, all nectars met this parameter. All processed nectar treatments showed a $\mathrm{pH}$ decrease over time. El-Sheikha et al., (2009) and Ruíz y Corral (2016) conducted studies on tomato juice and mixed nectar of sour grape, broccoli and blackberry respectively, which attributed the $\mathrm{pH}$ decrease to the possible presence of the Alicyclobacillus bacteria, especially of acid-producing bacteria such as Alicyclobacillus acidoterrestris. These microorganisms can grow in a very wide $\mathrm{pH}$ range, between 2.0 to 6.0 , generating problems in the juice industry (Batt and Tortorello, 2014). 
Titrable acidity: The content of titrable acidity in nectars made from beet juice, which data are not shown, had a minimum value $(0.17)$ in treatment 1 $\left(\mathrm{T}_{1}\right)$ at day 0 of storage, while the maximum value $(0.22)$ was observed in treatment 4 after 30 days of storage. The statistical analysis showed that there were significant differences ( $p$-value 0.000 ) on the acidity among the treatments plus the storage time. The treatments with the highest beet percentage were those that showed a higher acidity during the course of time; probably because of the higher amount of citric acid to standardize $\mathrm{pH}$ to 3.8. The results obtained in this parameter were similar to those obtained by Rakha et al., (2017), where the percentage of acidity was 0.25 in kiwi nectar. According to INEN (2008), acidity in nectars should not be higher than 0.6; thus, nectars based on beet are within the recommended range. The elaborated nectars showed an increase in the acidity values at all times of storage. The results obtained in the titrable acidity coincided with those obtained by El-Sheikha et al., (2009) and Ruíz y Corral (2016) previously described; in which the acidity increased during storage time, probably due to the presence of thermo-acidophilic bacteria, resulting in a $\mathrm{pH}$ decrease in tomato juice joined with nectar of mixed sour grape, broccoli and blackberry, respectively. Yadav et al., (2010) pointed out that the increase in acidity is due to the formation of organic acids.

Soluble solids: The content of soluble solids was a minimum value $\left(13.9^{\circ} \mathrm{Brix}\right)$ in nectars made in treatment $1\left(\mathrm{~T}_{1}\right)$ at 0 days of storage, while the maximum value obtained (14.6) was after 30 days in the nectars made in treatment $4\left(\mathrm{~T}_{4}\right)$ (data not shown). An increase in the content of soluble solids was produced between 0 and 30 days of storage in treatments $\left(\mathrm{T}_{0}, \mathrm{~T}_{1}, \mathrm{~T}_{3}\right.$ and $\left.\mathrm{T}_{4}\right)$, while treatment $\mathrm{T}_{2}$ exhibited an increase from 14 to $14.16^{\circ} \mathrm{Brix}$ between 0 and 15 days, but after day 30, it decreased to $14,06{ }^{\circ}$ Brix. The statistical analysis showed that there were significant differences (p-value 0.000) among the treatments plus the storage time on the soluble solids of the elaborated nectars. In general, all treatments showed a slight increase in the content of soluble solids, where treatment 4 $\left(\mathrm{T}_{4}\right)$ had a higher increase during the course of 30 days of storage, with an average of $14.16^{\circ} \mathrm{Brix}$ on day 0 and $14.53^{\circ}$ Brix after 30 days of storage. Bhardwaj and Pandey (2011) pointed out that the retention or a minimum increase in the content of soluble solids is considered optimal to preserve the juice quality. Raj et al., (2010) stated that the increase in soluble solids can be accredited to the conversion of complex carbohydrates into simple soluble carbohydrates.

Vitamin C: In reference to the elaborated nectars, a minimum value of ascorbic acid $(4.2 \mathrm{mg} / 100 \mathrm{~g})$ was shown in the control treatment $\left(\mathrm{T}_{0}\right)$ after 30 days of storage, while the maximum value $(10.06 \mathrm{mg} / 100 \mathrm{~g})$ was obtained on day 0 and after 15 days of storage in treatment $1\left(\mathrm{~T}_{1}\right)$. The treatments elaborated with the highest percentage of carrots-orange $\left(T_{1}\right.$ and $\left.T_{2}\right)$ had the highest content of ascorbic acid during the three storage times, showing an average content of ascorbic acid above $8 \mathrm{mg} / 100 \mathrm{~g}$. Treatment $3\left(\mathrm{~T}_{3}\right)$ was the one that showed a bigger decrease of ascorbic acid during the three storage times, showing a maximum value of $8.7 \mathrm{mg} / 100 \mathrm{~g}$ on day 0 and a minimum of 4.9 after 30 days. The treatments elaborated with a lower beet percentage showed, on the other hand, the lowest content of ascorbic acid during the periods of storage (Figure 1).

For the content of ascorbic acid or Vitamin $\mathrm{C}$, the statistical analysis showed that there were significant differences ( $p$-value 0.000) in the treatments and the storage time. The differences in the content of ascorbic acid in nectars based on beet was considered to happen due to the fact that orange had higher Vitamin C content than beet, which explained that those treatments with a lower beet percentage and higher carrot-orange percentage $\left(\mathrm{T}_{1}\right.$ and $\mathrm{T}_{2}$ ) could have a higher content of ascorbic acid. The values obtained in nectar based on beet were similar to those reported in other studies. Rakha et al., (2017) reported values between 4.6 to $20.6 \mathrm{mg} / 100 \mathrm{~g}$ of ascorbic acid in kiwi nectar. All processed nectars showed a decrease in Vitamin $\mathrm{C}$ content over time, this was supported by studies conducted by Rakha et al., (2017), Mgaya-Kilima et al., (2014) and Ziena (2000), who considered that the decrease in the content of Vitamin $\mathrm{C}$ was due to the fact that it was soluble in water, sensitive to oxygen, light and temperature, so it easily oxidized.

Reducing sugars: The minimum value (1.20) of the percentage of reducing sugars was obtained by the nectars made in the control treatment $\left(\mathrm{T}_{0}\right)$ on day 0 of storage (data not show). Meanwhile, the treatment that exhibited a maximum value (1.83) was treatment $4\left(\mathrm{~T}_{4}\right)$ after 30 days of storage. Statistical analysis showed significant differences on the content of reducing sugars between among 


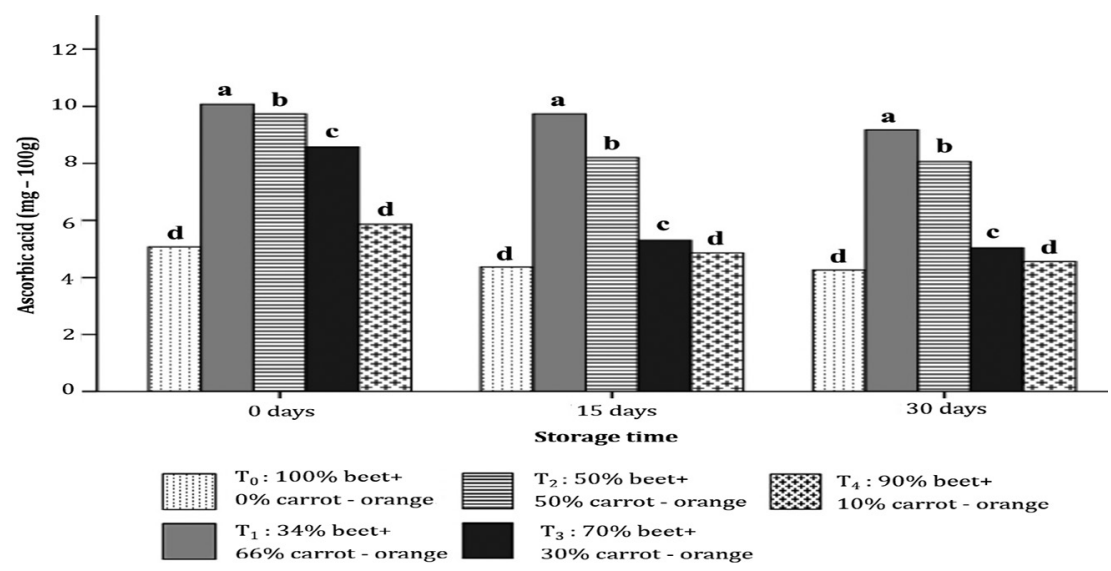

Figure 1. Average content of Vitamin C of nectars based on beet juice evaluated in 0, 15 and 30 days. (*) Different letters indicate statistically significant difference $\alpha=0.05$.

the treatments ( $\mathrm{p}-0,000$ value), plus the storage time (p-value 0,035 ). The results obtained on day 0 of storage indicated that, the higher the content of beet, the lower the percentage of reducing sugars was. This could be attributed to different proportions of reducing and non-reducing sugars in the species used in the elaboration of mixed nectar. The content of reducing sugars increased during the course of storage time in all nectars. Rakha et al., (2017) and Mgaya-Kilima et al., (2014) accredited the increase of reducing sugars in kiwi nectar and mixed hibiscus juice to the conversion of disaccharides into monosaccharides. Pareek et al., (2010) conducted studies on a tangerine juice and agreed with what was said above, adding that in a medium with low $\mathrm{pH}$, acids could turned into reducing sugars.

\section{Sensorial analysis}

Color: The color attribute showed a minimum score (2.30) in the nectar elaborated in treatment 1 $\left(\mathrm{T}_{1}\right)$. On the other hand, the maximum score (5.95) was obtained in the control treatment $\left(\mathrm{T}_{0}\right)$, followed by treatment $4\left(\mathrm{~T}_{4}\right)$ with a score of 5.85 . The minimum score (2.30) belonged to a lighter color while the maximum score (5.95) belonged to the darker color (Figure 2). The ANDEVA statistical analysis showed that there were significant differences (p-value 0.000) for the color attribute in the different treatments assessed by the panelist's sensorial perception. It was possible to observe that nectars made in treatments 1 and $2\left(\mathrm{~T}_{1}\right.$ and $\mathrm{T}_{2}$ ) showed values corresponding to lighter colors.
This can be explained because those treatments had a lower beet percentage in their formulation. On the other hand, treatments with the highest score, therefore, belonging to the darker colors, were the nectars made with a higher percentage of beets $\left(\mathrm{T}_{0}\right.$, $\mathrm{T}_{3}$ and $\mathrm{T}_{4}$ ). Lock (1997) indicated that the dark red color of beets has a great intensity, being bigger than many of the synthetic dyes, which would explain that a bigger beet concentration in the treatments would result in nectars with a darker color.

Aroma: That the minimum score (3.41) for the aroma attribute was obtained in the nectar

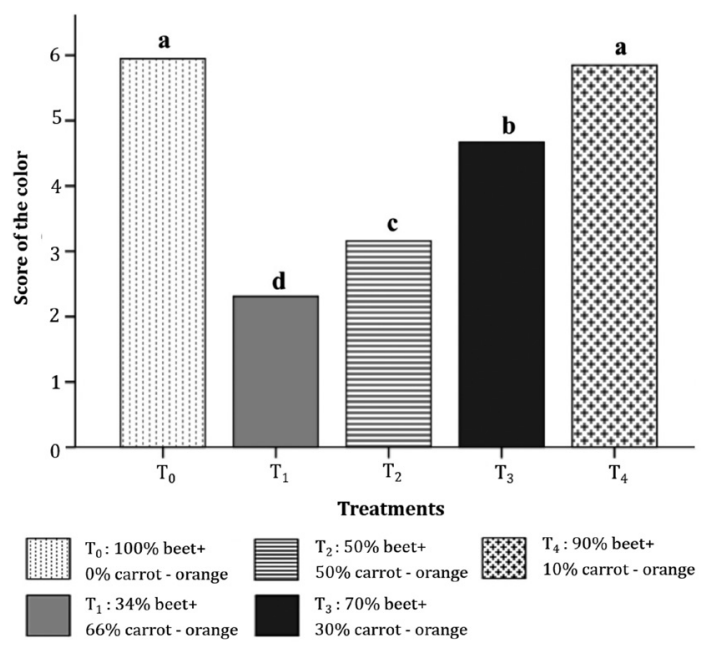

Figure 2. Average score of the color attribute of nectars based on beet juice evaluated by the panelist's sensorial perception after 30 days of storage, using a self-made color scale.

(*) Different letters indicate statistically significant difference $\alpha=0.05$. 
elaborated in treatment $1\left(\mathrm{~T}_{1}\right)$, while the maximum score (5.62) was achieved in the control treatment $\left(\mathrm{T}_{0}\right)$ (data not shown). According to ANDEVA statistical analysis, there were significant differences (p-value 0.000) among the treatments for the aroma attribute. Treatments 1 and $2\left(\mathrm{~T}_{1}\right.$ and $\left.\mathrm{T}_{2}\right)$ showed the lowest values with respect to the others, being in the middle range of the scale and ranging from 'less aromatic' to 'more aromatic'. In contrast, control treatments 3 and $4\left(\mathrm{~T}_{0}, \mathrm{~T}_{3}\right.$ and $\mathrm{T}_{4}$ ) showed the highest values, corresponding to 'more aromatic', according to the scale. Although treatment $3\left(\mathrm{~T}_{3}\right)$ had a significant difference with respect to the control treatment and $4\left(\mathrm{~T}_{0}\right.$ and $\left.\mathrm{T}_{4}\right)$, it had an average rating of 4 , that is why it was classified as one of the 'most aromatic' treatments. In regard to the score of the aroma attribute, it was highlighted that they were higher in nectars made in the treatments that contained the highest beet percentage in their formulation (higher than $70 \%$ ), such as treatment $\mathrm{T}_{0}, \mathrm{~T}_{3}$ and $\mathrm{T}_{4}$.

Viscosity: In reference to the assessment of the attribute viscosity, it showed a minimum score (2.15) in nectars made in the control treatment and $4\left(\mathrm{~T}_{0}\right.$ and $\left.\mathrm{T}_{4}\right)$, while the maximum score (2.56) was registered in treatment $1\left(\mathrm{~T}_{1}\right)$. It can be observed in figure 3 that all the treatments were found with a score belonging to a range of values between 2 and 3 which, according to the scale ranged from 'less viscous' to 'more viscous', placing them in a medium or moderate range. Although all treatments were in the same scoring range, ANDEVA statistical analysis indicated that there were significant differences (p-value 0.000) for the attribute viscosity in the different treatments; thus, the different treatments did influence on the perception of the viscosity attribute (Figure 3). Nectars made in treatments 1 and $2\left(\mathrm{~T}_{1}\right.$ and $\left.\mathrm{T}_{2}\right)$, that showed a higher viscosity score, belonged to treatments elaborated with a lower beet percentage (33-50\%) compared to treatments with the highest beet percentage 70-100\%) in their formulation, being these the witness treatments 3 and $4\left(\mathrm{~T}_{0}, \mathrm{~T}_{3}\right.$ and $\left.\mathrm{T}_{4}\right)$. Those treatments with a lower beet percentage contained a higher percentage of carrot-orange, where half of the percentage of such a mixture belonged to carrot juice and the other half to orange pulp. It can be inferred from this that the pulp is thicker than the juice; thus, it had an influence on the perception of the viscosity attribute. The differences regarding the perception of viscosity could be influenced by the content

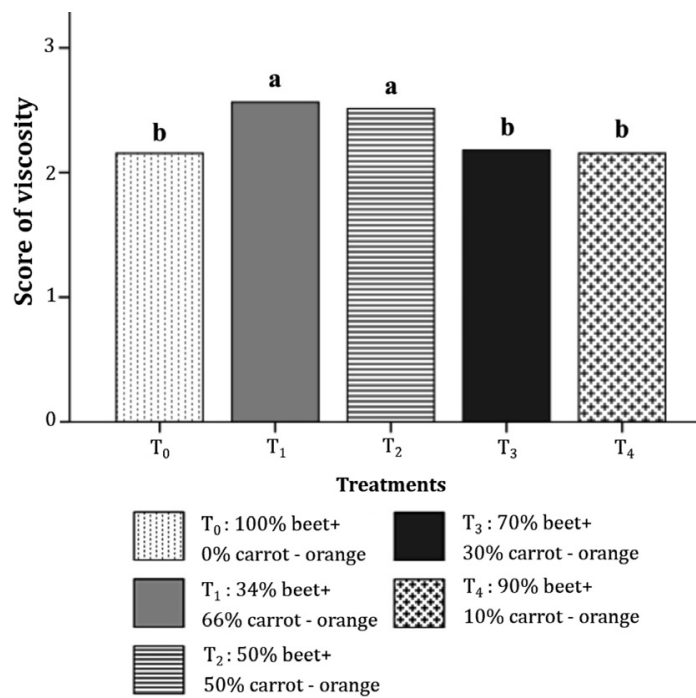

Figure 3. Average score of the viscosity attribute of nectars based on beet juice evaluated by the panelist's sensorial perception after 30 days of storage

(*) Different letters indicate statistically significant difference $\alpha=0.05$.

of muddiness, being this the blending of various materials present in a liquid (Marín, 2003).

Sweetness: The minimum score (3.69) of the sweetness attribute perceived by panelists belonged to nectars made in treatment $2\left(\mathrm{~T}_{2}\right)$ after 30 days of storage (data not shown). At the same time, the maximum score (4.51) was shown in the control treatment $\left(\mathrm{T}_{0}\right)$. ANDEVA statistical analysis indicated that there were significant differences (p-value 0.000) for the sweetness attribute in the different treatments. The treatments with the highest beet percentage $\left(\mathrm{T}_{0}\right.$ and $\left.\mathrm{T}_{4}\right)$ showed values belonging to the 'sweetest' category, according to the intensity scale for the measurement of the sweetness attribute. Meanwhile, treatments with beet percentage equaled or less than $70 \%\left(\mathrm{~T}_{1}, \mathrm{~T}_{2}\right.$ and $\mathrm{T}_{3}$ ) showed values belonging to a medium or moderate range, according to the same scale. Based on this, there was no significant influence on the different percentages of sucrose added, since the treatments that had a slight increase in additional sugar showed similar values, corresponding to a 'moderate sweetness'. Values obtained in the sensorial analysis for the sweetness attribute in treatment $4\left(\mathrm{~T}_{4}\right)$ coincided with the data obtained in the physicochemical analysis, where soluble solids showed a higher value in that treatment. However, the control treatment $\left(\mathrm{T}_{0}\right)$, that was also positioned 
in the 'sweetest' category, obtained a value of ${ }^{\circ} \mathrm{Brix}$ lower than treatment 4 and closer to treatments 1 , 2 and $3\left(\mathrm{~T}_{1}, \mathrm{~T}_{2}\right.$ and $\left.\mathrm{T}_{3}\right)$. Therefore, the perception of the sweetness attribute could be influenced by the beet percentage of and not by ${ }^{\circ} \mathrm{Brix}$.

Acidity: In regard to the perception of the attribute acidity, whose data are not shown, the minimum score (1.07) was obtained in the nectars made in treatment $2\left(\mathrm{~T}_{2}\right)$. Meanwhile, the maximum score belonged to nectars from treatment $4\left(\mathrm{~T}_{4}\right)$. In general, all nectars were within the range 1 to 2 in the acidity score, which classified them as 'less acidic', according to the intensity scale. The values obtained from the sensorial analysis with respect to the acidity attribute coincide with the data obtained from the physicochemical analysis of titratable acidity, where the highest value was obtained in treatment 4. The ANDEVA statistical analysis showed that there were no significant differences (p-value 0.146) for the attribute acidity, therefore, the different treatments did not influence on the perception of this attribute.

Acceptability: As can be observed in Figure 4, the score obtained for the acceptability of the processed nectars had a minimum value (5.87) in control treatment $\left(\mathrm{T}_{0}\right)$, while the maximum value (7.21) was obtained by the elaborated nectar in treatment $3\left(\mathrm{~T}_{3}\right)$. ANDEVA statistical analysis

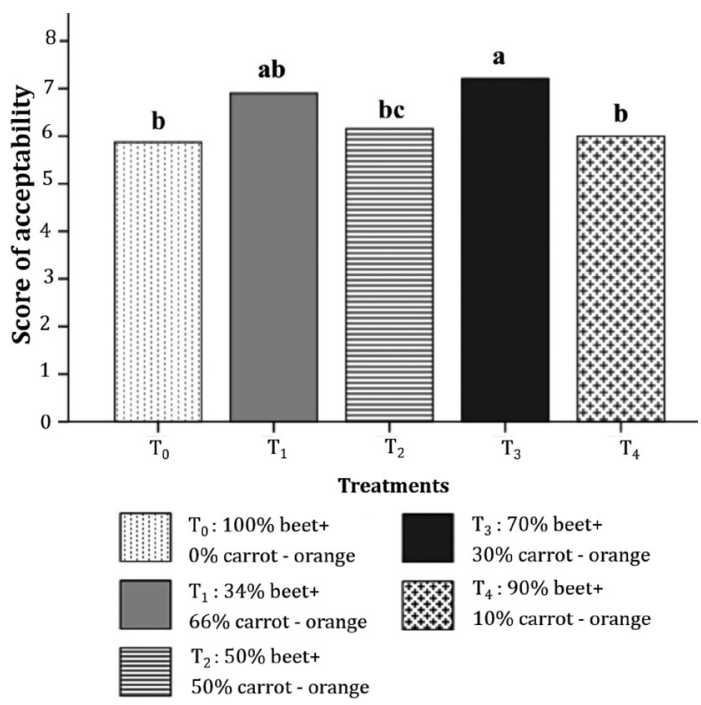

Figure 4. Average score of the acceptability attribute of nectars based on beet juice evaluated by the panelist's sensorial perception after 30 days of storage.

(*) Different letters indicate statistically significant difference $\alpha=0.05$. showed that there were significant differences (p-value 0.000 ) for the acceptability attribute among the different treatments (Figure 4).

The verbal hedonic scale that goes from 1 'I dislike it so much' to 9 'I like it very much', situated the witness treatment $\left(\mathrm{T}_{0}\right)$ in the category 'I do not like it' or 'I dislike it' with a score of 5.87, while the average of treatments 1,2 and $4\left(\mathrm{~T}_{1}, \mathrm{~T}_{2}\right.$ and $\mathrm{T}_{4}$ ) were classified in the category 'I slightly like it', with scores of 6.90, 6.15 and 6.00, respectively. On the other hand, the treatment with a higher acceptability, that is, treatment $3\left(\mathrm{~T}_{3}\right)$ was situated in the category 'I moderately like it', with a score of 7.21. The treatment with a higher acceptability $\left(\mathrm{T}_{3}\right)$ belonged to nectars made with $70 \%$ of beet in their formulation which, according to the previous data, belonged to dark colored nectars, highly aromatic, with medium viscosity, moderate sweetness and a low level of acidity. The treatment with the lowest acceptability $\left(\mathrm{T}_{0}\right)$ coincided in all the attributes with the treatment of higher acceptance, except for the sweetness attribute, which was described as 'very high'. Hence, it can be deduced that the sweetness perceived by the sensorial panelists had a significant influence on the acceptability of the different treatments. Costell (2001) states that the acceptance or rejection of a food is conditioned by food factors, characteristics of a consumer, either genetic, psychological or age related, and by the characteristics of the environment, being religious, geographical, educational and fashion ones, among others.

Microbiological analysis: The results obtained from the microbiological analysis indicated that nectars elaborated in the control treatments 1 and $3\left(\mathrm{~T}_{0}, \mathrm{~T}_{1}\right.$ and $\mathrm{T}_{3}$ ) did not present colony forming units. Meanwhile, nectars made in treatments 2 and 4 showed 13 and 36 colony forming units, respectively. Table 4 shows the limits of mesophilic aerobic microorganisms in non-carbonated soft drinks, according to the Sanitary Food Regulation Ministry of Health from Chile (2016), where ' $\mathrm{m}$ ' is the maximum limit of good quality and ' $\mathrm{M}$ ' is the maximum limit of acceptable quality. Thus, all nectars had a good quality since the mesophyll count showed a lower value than the one allowed $\left(10^{2}\right)$. The fulfillment of a good quality referred to the fact that the elaborated nectar presented a good sanitary and organoleptic quality, useful for life, the accomplishment of a cold chain and that the raw material used to elaborate them was correctly sterilized (Chile Alimentos, 2013). 
Table 4. Maximum limit of pathogenic microorganisms in non-carbonated non-alcoholic beverages.

\begin{tabular}{lll}
\hline & \multicolumn{2}{c}{ Limit per $\mathrm{mL}$} \\
\hline Parameter & $\mathrm{M}$ & $\mathrm{M}$ \\
Mesophilic aerobic microorganisms & $10^{2}$ & $10^{3}$ \\
\hline
\end{tabular}

Source: Adapted by the Ministry of Health from Chile, 2016.

\section{Conclusions}

The hypothesis of the present study was fulfilled since it was possible to elaborate nectars based on beet with sensorial acceptability, nutritional values and microbiological quality.

The physicochemical analyzes obtained on day 0 indicated that there were differences in all treatments for the acidity parameter. Thus, $\mathrm{pH}$ and the soluble solids were similar for all treatments due to their standardization during the elaboration of the nectars.

The results obtained from the nutritional analysis on day 0 indicated that there were significant differences in all treatments for the parameters Vitamin $\mathrm{C}$ and reducing sugars.

Regarding the behavior of the physicochemical parameters during the storage time, $\mathrm{pH}$ showed a decrease, but all treatments were located in an adequate range. Acidity showed an increase in all treatments, which was considered good, since a high acidity prevented the growth of microorganisms that could damage food. The content of soluble solids in the processed nectars showed a slight increase during storage, but remained in the optimum range for fruit and vegetable nectars.

In regards to the behavior of the nutritional parameters during the storage time, the content of Vitamin C decreased over time in all treatments, however, the percentage of reducing sugars showed an increase.

The sensorial analysis showed differences among the treatments for the attributes, color, aroma, viscosity and sweetness. The level of acidity perceived by the panelists was similar in all treatments.

Treatment $3\left(\mathrm{~T}_{3}\right)$, elaborated with $70 \%$ of beet and $30 \%$ of carrot-orange in its formulation, was the treatment with higher acceptability by panelists, obtaining an average of 7.21 out of a total amount of 9, which was classified as 'I moderately like it', according to the verbal hedonic scale used.

All nectars showed a mesospheric aerobic count lower than the range allowed by the Ministry of Health from Chile, thus all the elaborated nectars showed a good microbiological quality.

\section{Literature Cited}

Association of Official Analytical A.O.A.C.

1990. Chemists Official Methods of Analysis. 15th ed. $1298 \mathrm{p}$.

Baraona, M.; Sancho, E.

1991. Fruticultura especial, Fascículo 1. Cítricos. Fruticultura

II. Eds. Universidad Estatal a distancia. San José, Costa Rica. 116 p.

Batt, C.; Tortorello, M.

2014. Encyclopedia of food microbiology (2nd ed., Vol. 1). Eds. Academic Press. Amsterdam,Netherlands. 3248 p.

Berto, D. 2003. Bebidas não alcoólicas: apelo‘saudável’ impulsiona consumo. Food Ingredients, 24: 32-34.

Bhardwaj, R.J.; Pandey, S.

2011. Juice blends: A way of utilization of under-utilized fruits, vegetables, and spices. Food Sci. \& Nutr., 51: 563-570

Bielefeld, J.

2004. Zumos y bebidas saludables. Eds. Hispano Europea. Barcelona, España. 96 p.

Chile Alimentos.

2013. Parámetros microbiológicos en vegetales (Art. 173 del RSA). Santiago, Chile. 38 p.

Costel, E.

2001. La aceptabilidad de los alimentos: nutrición y placer. Arbor CLXVIII, 661: 65-85 pp.
El-Sheikha, A.; Ribeyre, F.; Larroque, M.; Reynes, M.; Montet, D. 2009. Quality of physalis (Physalis pubescens L.) juice packaged in glass bottles and flexible laminated packs during storage at $5{ }^{\circ} \mathrm{C}$. African Journal of Food and Agriculture Nutrition and Development, 9 (6): 1388-1405.

Espinosa, J.

2007. Evaluación sensorial de los alimentos. Editorial Universitaria.La Habana, Cuba. 116 p.

Hernández, E.

2005. Evaluación sensorial. Universidad Nacional Abierta y a distancia. Bogotá, D.C., Colombia. 128 p.

Instituto Ecuatoriano de Normalización.

2008. Jugos, pulpas, concentrados, néctares, bebidas de frutas y vegetales. Requisitos. Norma Técnica Ecuatoriana. INEN. Ecuador. 12 p.

Kehr, E.; Bórquez C.

2010. La zanahoria como una hortaliza apta para procesamiento agroindustrial. Tierra Adentro (INIA). 88: 17-19.

Marín, R.

2003. Fisicoquímica y microbiología de los medios acuáticos: Tratamiento y control de aguas. Eds. Díaz de Santos. Madrid, España. 336 p.

Mgaya-Kilima, B.; Remberg, S.F.; Chove, B.E.; Wicklund, T. 2014. Influence of storage temperature and time on the physicochemical and bioactive properties of roselle-fruit 
juice blends in plastic bottle. Food Science \& Nutrition, 2 (2): 181-191.

Ministerio de Salud de Chile.

2016. Reglamentos sanitario de los alimentos. República de Chile. Chile. 163 p.

Murray, M.; Pizzorno, J.; Pizzorno, L.

2005. The encyclopedia of Healing Foods. Eds. Atria Books. New York, US. 912 p.

Neelwarne, B.

2012. Red Beet Biotechnology: Food and Pharmaceutical Applications. Eds. Springer. US. 435 p.

Pareek, S.; Paliwal, R.; Mukherjee, S.

2010. Effect of juice extraction methods and processing temperatura-time on juice quality of Nagpur mandarin (Citrus reticulata Blanco) during storage. Journal of Food Science and Technology, 48 (2): 197-203.

Raj, D., Sharma, P.C., Vaidya, D.

2010. Effect of blending and storage on quality characteristics of blended sand pear-apple juice beverage. Journal of Food Science and Technology, 48 (1): 102-105.

Rakha, R.; Kumar, S.; Soni, A.; Singh, D.

2017. Qualitative and shelf life evaluation studies on kiwi fruit (Actinida deliciosa) nectar. International
Journal of Scientific Research and Management, 5 (4): 263-274.

Santibáñez, F.; Uribe, J.

1993. Atlas agroclimático de chile: Regiones sexta, séptima, octava y novena. Colaborador, Universidad de Chile. Departamento de ingeniería y suelos. Ministerio de agricultura, fondo de investigación agropecuaria. Santiago, Chile. 99 p.

ISO.

2013. ISO 4833-1. Microbiology of food chain. Horizontal method for the enumeration of microorganisms. Part 1: Colony count at $30{ }^{\circ} \mathrm{C}$ by the pour plate technique. International Standard Organization. Disponible en: https:// www.iso.org/standard/53728.html Consultado: 29/nov/2016.

Yadav, R.; Yadav, B.; Kalia, N.

2010. Development and storage studies on whey-based banana herbal (Mentha arvensis) beverage. Journal Food Technology, 5: 121-129.

Ziena, $\mathrm{H}$.

2000. Quality attributes of Bearss Seedless lime (Citrus latifolia Tan) juice during storage. Food Chemistry, 71: 167-172. 